\title{
Innovative contribution of subsidiaries to the parent company: a hypothesis about the relationship between an aerospace company and its subsidiary in Belo Horizonte
}

\author{
Bárbara Rangel de Carvalho Braga de Mendonça, Karla Rocha Liboreiro, Luana Lott Alves, Celso Yukio Nakashima, \\ Eduardo Romeiro Filho \\ Universidade do Estado de Minas Gerais - UEMG \\ e-mails: barbarademendonca@gmail.com; karlarliboreiro@gmail.com; luanalott@gmail.com; celyukio@yahoo.com.br; edu.romeiro@gmail.com
}

\begin{abstract}
This article presents how the subsidiaries can contribute to the generation of innovation in an aerospace company in a decentralized model. From the analyzed innovation network oriented by the Multinational corporation strategies were identified nine factors that favor the use of the subsidiary. The method consists of a qualitative case study carried out in a subsidiary of the aerospace sector with operations in Belo Horizonte. In order to confirm or refute the elaboration of the hypothesis about the use and contribution of CETE Belo Horizonte to the aerospace company's innovation process, the interview results are shown in association to the listed concepts, highlighting the critical points between the parent-subsidiary relationship.
\end{abstract}

Keywords: innovative performance, cross-classified factor contribution, open innovation.

\section{Introduction}

The decision of a Multinational Corporation (MNC) to deploy a subsidiary is influenced by different factors that may be technical, economic or political. MNC's subsidiaries can play key roles in the globalization of innovation, both as a source of expansion and as a combination of innovation capacity (PHENE; ALMEIDA, 2008).

In an MNC, the development and diffusion of knowledge and innovation are fundamental processes to its success, so it is necessary to avoid subsidiaries being isolated from other parts of the company (URZE; MANATOS, 2009). However, some authors report the difficulty of removing the subsidiaries from isolation and bringing them into the parent company's innovation system (BIRKINSHAW; HOOD, 2001). Thus, it is clear that fostering the innovation process in subsidiaries is a complex challenge, once it involves the alignment of multiple factors so that the process can get started and integration can take place.

The present case study seeks to evaluate the relationship between the parent company of an aerospace company with operations in Belo Horizonte (Minas Gerais, Brazil). The subsidiary is also known as Center of Engineering and Technology (CETE), from the innovation perspective. From the observation of the CETE's work routine, it is assumed that the company has decentralized production, product development, Research and Development (R\&D) and innovation-related decisions, but its structures, processes and mechanisms are still centralized, which makes it difficult to take advantage of the subsidiary as a source of innovation. Thus, it is assumed that the company still does not consciously and systematically take advantage of its subsidiary's innovation as a competitive advantage.

The literature review raises the main factors that favor the development of innovation in subsidiaries and their diffusion by MNCs. These factors were used as the basis for the creation of a semistructured interview script that was conducted with the general manager of the CETE, in order to find evidence of coherence between the presented assumption and the facts raised. Thus, the purpose of the paper is to refute the assumption or to formulate it as a hypothesis to be tested in future studies.

\subsection{The importance of decentralizing innovation and research and development}

The traditional view on innovation holds that the personal nature of knowledge and the uncertainties associated with $R \& D$ make innovation activities highly dependent on human interaction and rapid decisions, leading to a centralized model (FERNANDEZ-RIBAS; SHAPIRA; YOUTIE, 2007). In order to cut down on conflicts, the benefits of centralization would be from 
economies of scale, the scope of knowledge production, and information management and protection. On the other hand, the innovation environment is favored by several advantages associated with decentralization: host regional research infrastructure, smaller research costs, and access to local innovation networks. In addition, the geographical barriers are being increasingly reduced by the evolution of communication technologies.

If in the past innovation was centralized, with subsidiaries only adapting parent company solutions, from the 1990s it seems to be moving towards a decentralized model. According to the open innovation paradigm, companies focus their attention on the opportunities to use ideas and knowledge from outside their physical limits, so it is important to understand and follow the knowledge flow, that can be inwards or outwards (CHESBROUGH, 2003). The practice of open innovation can brings benefits such as shared risks/opportunities and joint technological competencies (CAETANO et al., 2011), and the reduction of time for technological development while providing competitive advantage (GONZÁLEZ et al., 2012).

With the globalization of productive activities, such organization model has been accentuated by global strategies in regional located subsidiaries. This institutional environment, according to Dias (2003) and Yeow and Blazjewski (2007), aim to gain competitive advantage by identifying local markets to reduce cost from the company's point of view, in order to elaborate a better performance for the whole corporation.

Thus, the decision to implement a subsidiary depends not only on factors such as proximity to large markets and cheap labor, but also on the rapid changes of traditional models of transfer of organizational knowledge facing geographical and political borders (BHAGAT et al., 2002). An important aspect of MNCs' competitive advantage is the ability of their foreign subsidiaries to generate innovation based on stimuli and resources resident in heterogeneous environments in their host country (FROST, 2001).

However, it is necessary to investigate the results of these influences in different types of subsidiaries (PHENE; ALMEIDA, 2008). Therefore, the need for research and understanding of how subsidiaries can integrate their parent's innovation strategies and the results provided by this integration justified further investigation.

\subsection{The company}

The aerospace company is currently one of the largest aerospace companies in the world. Its activities comprise the design, development, manufacture, sale and after-sales support of aircrafts. The company is in the market of commercial jets with up to 130 seats, the fifth largest executive jet manufacturer in the world. It has globally distributed offices and factories, employing around nineteen thousand employees in its global units, which keeps the company always at the forefront of technology since its foundation in the 1960s. Despite having initially developed a product aimed at the domestic market, requested products soon spread throughout the world. Therefore, it was necessary to have support units for maintenance and sales outside the country. It was from the privatization in the 1990s that it became a global company with global operations.

\subsection{CETEs - the decentralization of engineering}

The company's global expansion followed a classic sequence of an MNC. Initially, it sought greater proximity to consumer markets through sales and maintenance units. Subsequently, joint ventures and partnerships were organized to complement aircraft production and design capacity (BAGNO; LEIVA; OLIVEIRA, 2016). With the increase in sales, it expanded its production capacity nationally and internationally. The last stage was the decentralization of product development. As Dias (2003) shows, this diversification seeks to install, in the host countries, operations that take best advantage of their comparative advantages.

The CETEs emerged from the combination of a series of technical, economic and political factors, and were created from a strategic decision of global expansion of the company. The decentralization of engineering in strategic cities allowed access to skilled labor and proximity to customers, universities and research centers. In addition, geographic spreading has helped to reduce union pressures, which are very strong in the parent region. Finally, different public incentive policies attracted the interest of the company to some localities. Today, the company has CETEs in five units: São José dos Campos (head office in São Paulo, Brazil), Eugênio de Melo (São Paulo), Belo Horizonte (Minas Gerais), Melbourne (Florida, USA) and Évora (Portugal).

\section{Literature review}

The partial reading of the available literature allowed the team to identify some large areas that cluster several factors that favor the use of subsidiaries in the innovation network of MNCs. They are described in the next items.

\subsection{Strategy and guidelines}

The strategy starts with the identification of the main issues or issues of impact to the current business. It represents the main concerns of top management (LIMA, 2008). Its nature is associated with the high degree of uncertainty and impact on the future of the business, and should guide decision making, goal setting and action plans. Taking advantage of the decentralized innovation of a subsidiary start, first and foremost, with a strategic orientation of 
the MNC (FERNANDEZ-RIBAS; SHAPIRA; YOUTIE, 2007). According to Batsakis (2012), the autonomy in $\mathrm{R} \& \mathrm{D}$ of a subsidiary depends to a large extent from the parent company's authorization. The contribution to a MNC depends on the evolution of the subsidiary, which in turns tend to be the result of a local initiative and the designation provided by the parent (CANTWELL; MUDAMBI, 2003). Thus, it is possible to measure the contribution considering the level of decentralization in relation to innovative performance. The implementation of initiatives that may lead an organization to be more innovative requires deeper investigation on the gaps that separate the current status of a particular organization from the "desired" organization (BAGNO; LEIVA; OLIVEIRA, 2016). Hence, strategy and guidelines can drive the change needed for the innovation process.

\subsection{Knowledge flow}

The knowledge flow is spotted as an important element for MNC innovation by many authors (GUPTA; GOVINDAJARAN, 2000; CHESBROUGH, 2003; YEOW; BLAZJEWSKI, 2007). The attainment of knowledge is of strong interest to those who innovate through collaboration (CAUCHICK MIGUEL et al., 2013). According to Yeow and Blazjewski, (2007), the management efficiency will obtain competitive advantage from the knowledge flow across organizations. Some factors are reported to help the promotion of flow of knowledge: a collaborative organizational culture, fault tolerant leadership, positive corporate socialization, absorption capability, external context, infrastructure and trust culture. On the opposite side, the barriers for knowledge exchange are language and culture barriers, bureaucracy, lack of respect and trust, lack of continuity and short-term behavior (BIRKINSHAW; HOOD, 2001).

Companies usually strongly support knowledge flow from headquarters to subsidiaries but not in a reverse open transmission channel (GUPTA; GOVINDARAJAN, 2000). The reverse knowledge transfer has more chance to happen when the headquarter develops an organizational structure that allows the transference and use of the subsidiary knowledge, shares beliefs and values, and uses people-based mechanisms, like teamwork and transference of managers (PISCITELLO; RABBIOSI, 2006).

\subsection{Social capital}

The globalized social capital growth influences directly the human and financial resources productivity and the competitive advantage (WU; HSU, 2012). The social capital is defined as shared rules, values, institutions and relationships that allow a cooperation inside or outside different social groups (MARTELETO; SILVA, 2004). According the authors, such network construction - with the consequent acquisition of social capital - are shaped by cultural, political and social factors. And these factors need an administration different from the rigid economic relationship between the parts because it should incorporate diversified players. Therefore, it is evident the network structure behind this concept, which turns to be defined as a community resource built by its relationship networks.

The proximity with network partners builds a solid connection of personal relationships and trust that increase the apprenticeship efficacy and strengthen the subsidiary autonomy (ÓSKARSSON, 2005; CHING-SUNG; ZHI-CHENG, 2012). These authors emphasized themselves with shared visions and values, from the importance given on establishing internal relationships between the subsidiaries, transfer information and required resources in order to strengthen the innovation character of the whole organization.

\subsection{Absorptive capacity}

Several authors mention the absorptive capacity as a factor that foster the innovation in the subsidiaries (YEOW; BLAZJEWSKI, 2007; CANTWELL; MUDAMBI, 2003; FERNANDEZ-RIBAS; SHAPIRA; YOUTIE, 2007; PHENE; ALMEIDA, 2008; LEE; WU, 2010). This concept is defined as the capability to find and make use of new knowledge in a way that the organization uses the external knowledge to grow (TIDD; BESSANT, 2015). The absorptive capacity involves two complementary types of apprenticeship: the adaptive and the generative. The first one related to deal with the stabilization of routines inside the organization and the second to the development of new complexity levels (SENGE et al., 1994). It is necessary to consider that each organization has its own absorptive capacity taking into account several factors, such as: context, investment capital, market segment, people development, among others. Versiani et al. (2010) cite two types of knowledge that influence the absorptive capacity and the main related factors:

a) Previous knowledge: individual members capabilities, use of problem resolution methods, and shared language;

b) Knowledge transformation: education level, technical training, and experience.

The knowledge stock of the subsidiary can be a good indicator of its absorptive capacity (PHENE; ALMEIDA, 2008). Subsidiaries that contribute with R\&D tend to be older and have superior science and engineering capabilities, which may indicate the importance of accumulated experience and knowledge. Furthermore, the instruction degree of the workforce is important for the subsidiary 
innovation. (FERNANDEZ-RIBAS; SHAPIRA; YOUTIE, 2007)

\subsection{Resources}

To contribute to the company's innovation system, subsidiaries need guidance and resources. Guidance provides direction to be covered and resources enable development. Birkinshaw and Hood (2001) make two suggestions in this regard: provide resources to sow innovation and use proposal requisitions.

Fernandez-Ribas, Shapira and Youtie (2007) verified the influence of the size of the subsidiary in its R\&D engagement, indicating the hypothesis that it shall be an indirect measure of the subsidiary's infrastructure and financial resources.

\subsection{Autonomy}

As Piscitello and Rabbiosi (2006) argue, autonomy is a good measure of the degree of contribution that a subsidiary will creatively contribute to MNC knowledge networks. Subsidiary autonomy is a reliable indicator of the extent to which the subsidiary is organized to better leverage local networks and clusters and create an internal incentive structure that is more conducive to creativity and innovation among local workers and managers (PISCITELLO; RABBIOSI, 2006). According to Bartlett and Ghoshal (1989 apud PISCITELLO; RABBIOSI, 2006), the concept of differentiated network suggests that centralization limits the subsidiary's initiative. A low level of autonomy may reduce the subsidiary's initiatives in the exchange of intergroup knowledge (CANTWELL; MUDAMBI, 2003).

\subsection{Local context}

The context in which a subsidiary is located is important for its development as a creator of competencies (CANTWELL; MUDAMBI, 2003). In general, the most successful are located in places with good infrastructure and good scientific base. The more diverse and less concentrated the local environment, the greater the possibility of productive exchanges of knowledge. However, the local context may be irrelevant if the subsidiary is not able to embed itself in this environment, which is linked to its absorptive capacity and its autonomy.

The ability to merge locally and develop their own skills, through close relationships with local actors, impacts the ability to Reverse Transfer of Knowledge mentioned above (PISCITELLO; RABBIOSI, 2006). In addition, it is beneficial for the subsidiaries to relate to technologically active companies in their areas of expertise. The autonomy to collaborate with external actors also positively affects the innovative proficiency of the subsidiary (BATSAKIS, 2012).
R\&D investment is influenced by the quality of the workforce and opportunities for collaboration with universities in the subsidiaries (FERNANDEZ-RIBAS; SHAPIRA; YOUTIE, 2007). Therefore, the relationships of subsidiaries with localized sources of research become crucial for knowledge creation processes, as well as connections with clients, competitors and research institutions become central to the improvement of existing products and to the introduction of new technologies (PISCITELLO; RABBIOSI, 2006).

\subsection{Cross-fertilization}

Yamim, Sinkovics and Richardson (2014) investigated the importance of cross-fertilization in MNCs innovation capacity. It occurs in three main ways: trips of engineers and scientists to the subsidiaries, important mainly when the amount tacit knowledge is large; the use of modern communication technologies, which allow the discussion and exchange of information without the physical contact between the parties; and, finally, the conscious search of the MNCs by the subsidiary better qualified for a certain development. Factors that hinder cross-fertilization are lack of confidence, rivalries, and the "not invented here" syndrome. An important factor for the efficiency of the subsidiaries is that they have different capacities from the parent company.

\subsection{Hybridization}

Hybridization is the diffusion of processes, methods, practices and knowledge followed by successive adaptations to the local context, the phenomenon take place when a process is introduced to a new management model and is the result of the interaction between two systems, inserted in the homogenization process of the transference of knowledge, in different forms of collective action such as networks, clusters, alliances, subsidiaries or international activities, to achieve a common strategic action (YAHIAOUI; CHEBBI, 2008). This concept is suggested in a new context in which subsidiaries are valued and viewed as important actors that can transfer knowledge from the bottom up.

More than a local adaptation, knowledge transfer will not be possible if hybridization does not occur (BOYER, 1998). This includes, therefore, other management practices internal to the subsidiaries, such as organizational procedures, productive process, training programs, internal policies, among others. It is possible to increase the company's competitiveness by hybridized knowledge, by combining global and local $R \& D$ resources and competences available (considering the integration of an $\mathrm{MNC}$ and an institutional infrastructure, be it a campus of academic research, different R\&D centers or funded institutions), and therefore also considered an organizational innovation (ASHEIM; ISAKSEN, 1997). 


\section{Methodology}

The methodology chosen for the present study was the Case Study (YIN, 2001), which proved to be adequate in view of the objective and the hypothesis of the investigation, of explanatory character and qualitative nature. Also this methodology is recommended due to the complexity of the investigated problem, which must consider the competitiveness landscape of the market with an intense level of product integration for the investigated area of the company. Araujo (2012) considers the case study method potential since

$[\ldots]$ in this path many new management strategies, approaches and solutions are developed and continually implemented into the practice of industry, in special by companies involved with high-technology products, due to the fast moving pace of these sectors.

The documentary analysis, whose objective is the condensed representation of the information to facilitate the consultation and manipulation of data (BARDIN, 2016), was carried out later. The research followed the following sequence:

a) Search based on the literature, of the main factors that foster innovation in subsidiaries;

b) Elaboration of a semi-structured interview script for the application to the general manager of CETE, in order to understand the innovation process and the relevant factors that are practiced according to its point of view;

c) Conducting the interview with the manager;

d) Analysis of results;

e) Final considerations.

These steps were used to confirm or refute the elaboration of the hypothesis about the use and contribution of CETE Belo Horizonte to the aerospace company's innovation process.

As the main instrument of analysis, a semi-structured interview was conducted in depth with a manager of the CETE in Belo Horizonte. The semi-structured interview script consisted of open questions based on the literature review, in order to allow the researchers to understand in depth the interviewee's point of view. After the interview, content analysis was performed (BARDIN, 2016). Talks were characterized that, during the interview, demonstrated factors that foster innovation: Strategy and Guidelines; Knowledge flow; Share capital; Absorption capacity; Resources; Autonomy; Local Context; Cross-fertilization and Hybridization.

\section{Analysis of results}

During the process of analysis of results, it was possible to associate the concepts listed in the light of the theory with the vision of a manager interviewed. In general lines,
CETE is defined as a center of technological and product development, not a center of research and innovation. CETE's primary responsibility is to develop "work packages" or "service packages" for product development within areas such as software, simulation, and other. In this way, there is no deliberate strategy by the Matrix for CETE to act systematically in the search for innovation, since the parent company does not define innovation goals for them. The Office's contribution to innovation therefore takes two forms:

a) Spontaneous, referring both to process innovations that occur when employees, for example, develop a faster way of doing a service to the parent company, and ideas that are sent to the "Good Idea Award" initiative;

b) Directed, in topics defined by the parent company within Technological Development programs, and by work calls, such as the "Innova Program".

In this way, the innovation, for the most part, is centralized and directed by the parent company, with low autonomy of the subsidiary in the definition of topics of interest. According to the interviewee, the office has enough autonomy to execute and develop the product, but only within what is prescribed. When it comes to research and innovation, the definitions are of the parent company, because today technological development is centralized in São José dos Campos.

In the following paragraphs, the analysis of the results will be described, having as theoretical background the factors described previously in this work. The strategies and guidelines are generated in the Matrix, in São José dos Campos, and directed to CETE. In this way, the absence of a defined strategic goal was confirmed so that it contributes to the matrix's innovation processes. According to the interviewee, the center's responsibility is more operational, in the development of products in the form of "work packages", in addition to support activities. Innovation is not one of the goals of the Center and is perceived as a tool to improve the efficiency of the work done to the parent, and is not defined as an end to CETE.

The first thing for the Engineering Center to be better
leveraged in terms of innovation should be the goal:
to make innovation so that you are measured by it [...].
When these three centers began, a deeper strategic plan
was not made as to how these Centers would make their
contributions (INTERVIEWED).

Regarding the flow of knowledge, CETE develops innovations in the areas of software development and simulation. However, it is not known if the innovations developed locally are incorporated by the parent company or the other subsidiaries, since there is no follow-up after 
the disclosure. According to Araujo (2012) government entities and research support organizations, either in Brazil or outside, have been increasingly and consistently supported partnership initiatives, with an emphasis on projects involving cooperation among research institutions and industry.

Taking into account the local context, the city of Belo Horizonte has several universities and industries which enable knowledge exchange. There are managers participating in courses and initiatives from universities and business schools, such as the Federal University of Minas Gerais, Fundação Dom Cabral and PUC-MG. There is a search for updating new technologies, through the contact of employees with professors and researchers, either in the participation of innovation events or in attendance to courses in technological areas of interest to the aerospace company. When CETE installed itself, there was an analysis of good teaching institutions that trained the skilled workforce, mainly in the engineering areas. Currently, there are projects being carried out in partnerships with universities, as in the area of flight simulation through FAPEMIG, the research support state foundation.

The subsidiary comprises the areas that needed growth and could be carried out far from the parent company: systems simulation, software development and certification, computational and load dynamics of aeronautics, and structure analysis and design. To that end, human resources are mostly engineers and specialists.

Regarding financial resources, these are driven by the center's needs-end. There are limitations in using resources to incorporate innovations as part of the routine and for extra activities such as participation in innovation events. In this way, there is limited financial resources to incorporate innovations as part of the routine, as this could jeopardize product development deliveries.

Concerning the Social Capital, once CETE staff are short-time employees, it tends to be more flexible in terms of innovation and methodological changes. However, the manager reports that even with a younger workforce, it is more difficult to innovate with already established technologies in the company, which directs the innovation to the areas with little time of operation. Other factors reported by the manager in the parent-subsidiary relationship were: the existence of cultural proximity, relationships of respect and trust, and innovations generated in cooperation.

In terms of absorptive capacity, the office has several positive factors in the literature: high educational level, interactions between experienced and new employees, cultural diversity with people from several states and a search for external knowledge and new ways of performing services. Both the potential exists that the office already contributes with spontaneous innovations (Good Idea) and directed (Technological Development packages and Innova Program).

The manager perceives a high autonomy degree of the CETEMG to develop the products, factor facilitated by the distance of the parent company. However, this development autonomy occurs only in the areas of expertise of the subsidiary. In addition, it is limited by the activities planned to be carried out by CETE. When the center engages in research activities, these are obtained as a "service package" within the larger technology development project that is currently centered on the parent company.

In the aerospace company the importance of cross-fertilization is given through business trips and direct contacts for knowledge transfer. Along with training programs or by employees transferring from São José dos Campos to Belo Horizonte, which facilitates communication and allows the discussion and exchange of information from the parent to the subsidiary.

Finally, according to the interviewee, hybridization is perhaps the most critical point in the parent-subsidiary relationship. There is not yet a systematization to adapt the practices of the parent company (such as the Normative System) to the subsidiaries. According to the interviewee, we must understand that this aerospace company is a global company, and that some practices need to be locally adapted.

\section{Conclusion}

The innovation management is a critical activity because it supports the strategic direction, guides the resources allocation, create new capabilities and generate new knowledge, making enterprises more competitive (CAUCHICK MIGUEL; CARVALHO; LOPES, 2013). In this order, the main factors showed by the literature review that could indicate a formal and efficient use of the subsidiaries in the process of innovation of an MNC were raised. With this, it was possible to prepare a questionnaire to conduct the interview to obtain indications of the use of CETE MG in aerospace company's innovation processes. Due to the complexity of the subject, it is considered that the research carried out was not exhaustive in the sense of confirming or refuting the use, but there is a lot of evidence that systematic and formal use of the office is only incipient and centralized.

As the analysis shows, although several elements point out that CETE-MG is a potential source of innovation, the company strategy does not officially consider the office in its innovation guidelines. Despite the many contributions already made locally, the center has limitations of autonomy and resources to innovate. And even if there are local process innovations, it is not known whether they are used in other MNC dimensions. The directions and definitions of the themes of research, innovation and technological 
development are done centrally, from the parent company to the subsidiary.

Based on the results obtained, it is considered coherent to formulate the hypothesis that the aerospace company does not consciously and systematically take advantage of the innovation of its subsidiary as a competitive advantage. The confirmation or refutation of this hypothesis, however, can only be done after a thorough study: a more specific bibliographical review and the involvement of several other actors in the interviews and inquiries, both in the subsidiary and in the parent company. Further investigative research with other companies is advised in order to validate the points discussed in this article.

\section{Acknowledgements}

The authors thank the company and the manager who made this research possible. They also thank the institutions that sponsor the research grants of the authors: FAPEMIG, CAPES and CNPq.

\section{References}

ARAUJO, C. S. Lessons learned on the planning and execution of technology innovation projects with academic partnership: aerospace industry case study. Product: Management \& Development Journal, v. 10, n. 1, p. 4151, 2012.

BAGNO, R. B.; LEIVA, T. L.; OLIVEIRA, L. G. H. Innovation management: lessons learned from innovation diagnostic tools. Product: Management \& Development Journal, v. 14, n. 1, p. 12-21, 2016.

BARDIN, L. Análise de conteúdo: edição revista e ampliada. São Paulo: Edições 70, 2016.

BATSAKIS, B. R\&D Subsidiaries? Innovative performance? Revisited: a multilevel approach. In: DRUID CONFERENCE, 2012, Copenhagen, Denmark. Proceedings... Copenhagen: DRUID, 2012. p. 1-39.

BHAGAT, R. S. et al. Cultural variations in the cross-border transfer of organizational knowledge: An integrative framework. Academy of Management Review, v. 27, n. 2, p. 204-221, 2002.

BIRKINSHAW, J. E.; HOOD, N. Unleash innovation in foreign subsidiaries. Harvard Business Review, v. 79, n. 3, p. 131-137, 2001.

BOYER R. Hybridization and models of production: geography, history and theory. In: BOYER, R.; CHARRON, E.; ULRICH, J.; TOLLIDAY, S. Between Imitation and Innovation: the transfer and hybridization of productive models in the international automobile industry. Oxford: University Press, 1998. p. 23-56.

CAETANO, M. et al. Open innovation and technology development process: the gap on partnership adoption from a case study perspective. Product: Management \& Development, v. 9, n. 2, p. 111-120, 2011.

CANTWELL, J.; MUDAMBI, R. On the nature of knowledge creation in MNE subsidiaries: an empirical analysis using patent data. In: SPRU CONFERENCE IN HONOUR OF KEITH PAVITT. WHAT DO WE KNOW ABOUT INNOVATION, 2003, Brighton, England. Proceedings... Brighton: SPRU, 2003. p. 13-15.

CAUCHICK MIGUEL, P. A.; CARVALHO, M. M.; LOPES, A. P. A pilot case study of open innovation in a Brazilian company. Product: Management \& Development, v. 11, n. 2, p. 136-141, 2013.

CHESBROUGH, H. W. Open innovation: the imperative for creating and profiting from technology. Boston: Harvard Business School Publishing Corporation, 2003.

CHING-SUNG, W. E; ZHI-SHENG, H. Subsidiary innovation in multinational corporation: social capital perspective. The Journal of Human Resource and Adult Learning, v. 8, n. 2, p. 65-72, 2012.

DIAS, A. V. C. Produto mundial, engenharia brasileira: integração de subsidiárias no desenvolvimento de produtos globais na indústria automobilística. 2003. 303f. Tese (Doutorado em Engenharia)-Universidade de São Paulo, São Paulo, 2003.

FERNANDEZ-RIBAS, A.; SHAPIRA, P.; YOUTIE, J. Traditional versus decentralized innovation strategies of multinational enterprises. Atlanta: GeorgiaTech School of Public Policy, 2007. (Working Paper Series, n. 22).

FROST, T. S. The Geographic Sources of Foreign Subsidiaries' Innovations. Strategic Management Journal. v. 22, n. 2, p. 101-123, 2001.

GONZÁLEZ, M. O. A. et al. Open innovation practices in the development of wind energy supply chain: an exploratory analysis of the literature. Product: Management \& Development, v. 10, n. 2, p. 104-111, 2012.

GUPTA, A. K.; GOVINDARAJAN, V. Knowledge flows within multinational corporations. Strategic Management Journal, v. 21, n. 4, p. 473-496, 2000.

ISAKSEN, A.; ASHEIM, B. Location, Agglomeration and innovation: towards regional innovation systems in Norway? European Planning Studies, v. 5, n. 3, p. 299330, 1997.

LEE, C. Y. L.; WU, F. C. Factors affecting knowledge transfer and absorptive capacity in multinational corporations. Journal of International Management Studies, v. 5, n. 2, p. 118-126, 2010.

LIMA, P. V. L. Gestão estratégica: o caminho para a transformação. Nova Lima: INDG, 2008. 
MARTELETO, R. M.; SILVA, A. B. O. Redes e capital social: o enfoque da informação para o desenvolvimento local. Ciência da Informação, v. 33, n. 3, p. 41-49, 2004.

ÓSKARSSON, G. Factors that have an impact on the exploitation of external knowledge in continuous product innovation processes. Rannsóknir í félagsvísindum VI, v. $157,2005$.

PHENE, A.; ALMEIDA, P. Innovation in multinational subsidiaries: the role of knowledge assimilation and subsidiary capabilities. Journal of International Business Studies, v. 39, n. 5, p. 901-919, 2008.

PISCITELLO, L.; RABBIOSI, L. How does knowledge transfer from foreign subsidiaries affect parent companies' innovative capacity. In: DRUID SUMMER CONFERENCE, 6., 2006, Copenhagen, Denmark. Proceedings... Copenhagen: Copenhagen Business School. n. 6, p. 1-24.

SENGE, P. et al. The fifth discipline field book strategies and tools for building a learning organization. New York: Currency Doubleday, 1994. p. 593.

TIDD, J; BESSANT, J. Gestão da inovação. 5. ed. Porto Alegre: Bookman Editora, 2015.

URZE, P.; MANATOS, M. J. Mapping R\&D within Multinational Networks: Evidence from the Electronics Industry. In: CAMARINHA-MATOS, L. M., PARASKAKIS, I., AFSARMANESH, H. (Ed.). Leveraging Knowledge for Innovation in Collaborative Networks. IFIP Advances in Information and Communication Technology. Berlin, Heidelberg: Springer, 2009. v. 307, p. 96-105.

VERSIANI, A. F. et al. Mensuração da Capacidade Absortiva: até que ponto a literatura avançou? In: ENCONTRO NACIONAL DA ASSOCIAÇÃO NACIONAL DE PÓSGRADUAÇÃO E PESQUISA EM ADMINISTRAÇÃO, 2010, Rio de Janeiro. Anais... Rio de Janeiro: ANPAD, 2010. n. 34, p. 25-29.

WU, C. S.; HSU, Z. S. Subsidiary innovation in multinational corporation: social capital perspective. The Journal of Human Resource and Adult Learning, v. 8, n. 2, p. 6572, 2012.

YAHIAOUI, D.; CHEBBI, H. The limits of top-down transfers within a multinational corporation: the need for knowledge hybridization. Journal of Innovation Economics \& Management, n. 2, p. 85-104, 2008.

YAMIN, M.; SINKOVICS, R. R.; RICHARDSON, C. Internationalisation of innovative activity in Finnish multinational enterprises. European Journal International Management, v. 8, n. 3, p. 310-330, 2014.

YEOW, P. E.; BLAZJEWSKI, S. Knowledge and innovation: opportunities and challenges to knowledge transfer between multinationals and their subsidiaries. Reino Unido: University of Kent, 2007. (Working Paper Series Kent Business School, n. 154).

YIN, R. K. Estudo de caso: planejamento e métodos. Porto Alegre: Bookman, 2001. 